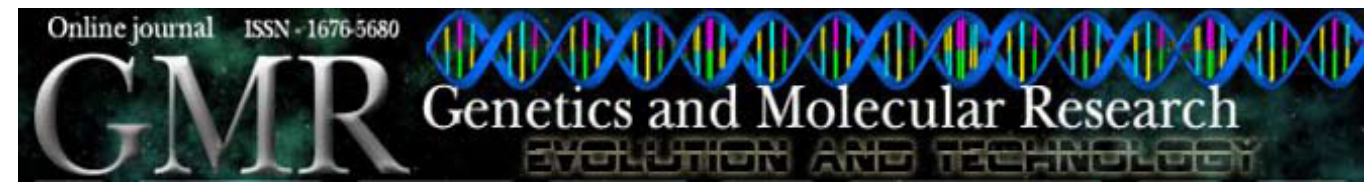

\title{
Rapid and inexpensive analysis of genetic variability in Arapaima gigas by PCR multiplex panel of eight microsatellites
}

\author{
I.G. Hamoy, E.J.M. Santos and S.E.B. Santos \\ Laboratório de Genética Humana e Médica, Centro de Ciências Biológicas, \\ Universidade Federal do Pará, Belém, PA, Brasil \\ Corresponding author: I.G. Hamoy \\ E-mail: ighamoy@yahoo.com.br
}

Genet. Mol. Res. 7 (1): 29-32 (2008)

Received September 19, 2007

Accepted December 17, 2007

Published January 22, 2008

\begin{abstract}
The aim of the present study was the development of a multiplex genotyping panel of eight microsatellite markers of Arapaima gigas, previously described. Specific primer pairs were developed, each one of them marked with either FAM-6, HEX or NED. The amplification conditions using the new primers were standardized for a single reaction. The results obtained demonstrate high heterozygosity (average of 0.69 ) in a Lower Amazon population. The multiplex system described can thus be considered a fast, efficient and inexpensive method for the investigation of genetic variability in Arapaima populations.
\end{abstract}

Key words: Arapaima gigas; Pirarucu; Microsatellites;

Multiplex polymerase chain reaction; Conservation genetics;

Lower Amazon 


\section{INTRODUCTION}

Arapaima gigas is the largest tropical fresh water fish, reaching up to $3 \mathrm{~m}$ in length and $200 \mathrm{~kg}$ (Saint-Paul, 1986). Arapaima is distributed mainly in the flooded regions of the Amazon Basin, locally known as pirarucu, and in the upper Essequibo River in Guyana (Lüling, 1964).

Traditionally, Arapaima has been of great importance in the diet of Amerindians living on the Amazon region rivers. From the early 18th century on, fishing Arapaima became commercially important for the Amazon Basin people. This economic importance has lasted from the colonial times to the present days. Due to overfishing, A. gigas is one of the few fish species listed in the Convention on International Trade in Endangered Species of Wild Fauna and Flora II. Despite its economic importance, little is known about its genetic structure and its population distribution in the Amazon (Farias et al., 2003; Hrbek et al., 2005).

Estimating the genetic diversity of natural populations is one of the most important forms of evaluating a species' viability. For most fish species, this kind of investigation has been centered on the analysis of the variability of microsatellite markers (PerezEnriquez et al., 1999).

Fourteen different microsatellites of Arapaima have been described (Farias et al., 2003). However, the individual genotyping of several microsatellite markers is costly and time consuming. A way of reducing costs and optimizing analysis is the use of multiplex microsatellite polymerase chain reaction (PCR), as it amplifies several microsatellites in a single PCR and allows the electrophoresis of all amplified fragments in a single capillary or lane (Neff et al., 2000).

In the present study, we describe the development of a multiplex panel of eight microsatellite markers of Arapaima. We used this multiplex genotyping system to verify the level of genetic variability in the natural population of Arapaima in the Lower Amazon.

\section{MATERIAL AND METHODS}

A total of 32 samples of Arapaima were caught in Sauaçu Lake in the Juruti municipality in the Lower Amazon, Pará State, Brazil. An amount of $10 \mathrm{~g}$ of muscle tissue was collected from each individual, preserved in $95 \%$ ethanol, and stored at $4{ }^{\circ} \mathrm{C}$. Total genomic DNA was extracted from tissue digested in a proteinase $\mathrm{K} /$ sodium dodecyl sulfate solution, and DNA purification was by the standard phenol/chloroform method, followed by precipitation with isopropanol (Sambrook et al., 2001).

From the 14 microsatellites isolated by Farias et al. (2003), eight markers were selected (AgCAm2, AgCAm13, AgCAm15, AgCAm16, AgCAm18, AgCTm3, AgCTm5, $\mathrm{AgCTm} 7)$ based on the highest level of polymorphism of each microsatellite. For each marker, new primer pairs were developed using the program Primer3 (Rozen and Skaletsky, 2000). Each new forward primer was marked with one of the following fluorescent dyes: FAM-6, HEX or NED (Table 1). All primers had the same annealing temperature and all markers with the same fluorescent dye amplified fragments were of different sizes to avoid allele overlapping.

Multiplex PCR was carried out in $20-\mu \mathrm{L}$ reaction volumes containing $5.5 \mu \mathrm{L}$ double- 


\begin{tabular}{|c|c|c|c|c|c|c|c|}
\hline $\begin{array}{l}\text { Locus GenBank } \\
\text { Accession No. }\end{array}$ & Repeat motif & Primer $\left(5^{\prime}-3^{\prime}\right)$ & Dye & $\begin{array}{l}\text { Size range } \\
\quad(\mathrm{bp})\end{array}$ & $n_{\mathrm{A}}$ & $H_{\mathrm{O}}$ & $H_{\mathrm{E}}$ \\
\hline $\begin{array}{l}\mathrm{AgCAm} 16 \\
\mathrm{AY} 176183\end{array}$ & $(\mathrm{CA})_{19}$ & $\begin{array}{l}\text { F: GCAAGCAGTAAAGAAAGGACAGA } \\
\text { R: AACGGACCCACTTCTCTATGTG }\end{array}$ & HEX & $91-105$ & 10 & 0.78 & 0.83 \\
\hline $\begin{array}{l}\operatorname{AgCAm} 15 \\
\mathrm{AY} 176181\end{array}$ & $(\mathrm{CA})_{19}$ & $\begin{array}{l}\text { F: GGCATCAAATGTGACTGCTACT } \\
\text { R: GAACAAGGCTAGATTGCAAAGTT }\end{array}$ & FAM-6 & $128-144$ & 4 & 0.59 & 0.61 \\
\hline $\begin{array}{l}\operatorname{AgCAm} 13 \\
\text { AY } 176180\end{array}$ & $(\mathrm{GTA})_{2}(\mathrm{CA})_{27}$ & $\begin{array}{l}\text { F: TGTTTCCAACTGTGTCCAACA } \\
\text { R: TGCTGTAAACACCAGTTACCTCA }\end{array}$ & HEX & $135-169$ & 10 & 0.71 & 0.75 \\
\hline $\begin{array}{l}\mathrm{AgCTm} 3 \\
\mathrm{AY} 176173\end{array}$ & $(\mathrm{CT})_{15}$ & $\begin{array}{l}\text { F: CAAAAGGATTGCCTGTTAGGG } \\
\text { R: CCAGGTATGAGTTTTGCAAGGT }\end{array}$ & NED & $138-146$ & 5 & 0.78 & 0.75 \\
\hline $\begin{array}{l}\mathrm{AgCTm} 5 \\
\mathrm{AY} 176175\end{array}$ & $(\mathrm{CT})_{28}$ & $\begin{array}{l}\text { F: AAGGATCGATACATCAAGAGCTTC } \\
\text { R: CTCCCTCTGTGGTGCTACAAT }\end{array}$ & NED & $175-191$ & 5 & 0.56 & 0.65 \\
\hline $\begin{array}{l}\operatorname{AgCAm} 18 \\
\mathrm{AY} 176183\end{array}$ & $\begin{array}{l}(\mathrm{GA})_{2}(\mathrm{CA})_{9} \mathrm{CTC} \\
\mathrm{AAACT}(\mathrm{CA})_{20}\end{array}$ & $\begin{array}{l}\text { F: CTCAACTGTGATGCTGGGAAT } \\
\text { R: CTTTGGCCCAGGATAAACAA }\end{array}$ & FAM-6 & $175-193$ & 6 & 0.59 & 0.60 \\
\hline $\begin{array}{l}\mathrm{AgCAm} 2 \\
\mathrm{AY} 176178\end{array}$ & $(\mathrm{CA})_{22}$ & $\begin{array}{l}\text { F: AGGAGATGCAAACACCCTGTA } \\
\text { R: CCGATCATCTGTTTGCTCTGT }\end{array}$ & HEX & $217-247$ & 13 & 0.90 & 0.84 \\
\hline $\begin{array}{l}\mathrm{AgCTm} 7 \\
\mathrm{AY} 176176\end{array}$ & $(\mathrm{CT})_{29}$ & $\begin{array}{l}\text { F: AAGGATCGATACATCAAGAGCTTC } \\
\text { R: ACGGTGAATATCTGTGCTTGG }\end{array}$ & FAM-6 & $233-259$ & 11 & 0.65 & 0.76 \\
\hline
\end{tabular}

$n_{\mathrm{A}}=$ number of alleles per locus; $H_{\mathrm{O}}=$ observed heterozygosity; $H_{\mathrm{E}}=$ expected heterozygosity.

distilled $\mathrm{H}_{2} \mathrm{O}, 2.0 \mu \mathrm{L}$ 10X buffer (100 mM Tris- $\left.\mathrm{HCl}, 500 \mathrm{mM} \mathrm{KCl}\right), 0.7 \mu \mathrm{L} \mathrm{MgCl}_{2}(15 \mathrm{mM})$, $9.6 \mu \mathrm{L}$ primer mix $(0.3 \mu \mathrm{M}$ of each forward and reverse primer), $1.0 \mu \mathrm{L}$ dNTP $(200 \mu \mathrm{M}$ of each dNTP), $0.2 \mu \mathrm{L}$ of Platinum ${ }^{\mathrm{TM}} \mathrm{Taq}$ DNA polymerase (Invitrogen) $(5 \mathrm{U} / \mu \mathrm{L}), 1 \mu \mathrm{L}$ of DNA (10 ng). PCRs were run on a Perkin Elmer GeneAmp 9700 with initial denaturation at $94^{\circ} \mathrm{C}$ for $11 \mathrm{~min}$, followed by 30 cycles at $94^{\circ} \mathrm{C}$ for $30 \mathrm{~s}, 60^{\circ} \mathrm{C}$ for $30 \mathrm{~s}, 72^{\circ} \mathrm{C}$ for $30 \mathrm{~s}$, and final a extension at $72^{\circ} \mathrm{C}$ for $30 \mathrm{~min}$. Products were visualized in Applied Biosystems 3130 Genetic Analyzer. Allele sizes were stipulated using the size standard GeneScan 500 (Rox) (Applied Biosystems). Consistent allele designation and typing quality were assured by simultaneous electrophoresis analysis of an allele sample of known size. Samples were genotyped using the software GeneMapper 3.7 (Applied Biosystems).

The primers developed were validated by direct sequencing of each microsatellite of homozygous individuals. Individual PCRs were carried out for each system without the use of marked primer. Sequencing reactions were performed with BigDye ${ }^{\circledR}$ v3.0 (Applied Biosystems) kit. The sequencing products were visualized in the Applied Biosystems 3130 Genetic Analyzer.

We analyzed the genetic variability using the observed and expected heterozygosity and Hardy-Weinberg equilibrium deviations. We also estimated the allele number per locus and compared the proportion of locus pairs in linkage disequilibrium. All tests were carried out using the software Arlequin 3.01 (Excoffier et al., 2005) with the Bonferroni correction.

\section{RESULTS}

The observed heterozygosity found in the Arapaima population of the Lower Amazon showed an average of 0.69 , with the allele number per locus ranging from four ( $\mathrm{AgCTm} 5)$ to thir- 
teen (AgCAm2), an average of 8.0 alleles. None of the loci displayed significant Hardy-Weiberg equilibrium deviations. There were no locus pairs with significant linkage disequilibrium.

\section{DISCUSSION}

The observed heterozygosity value found was high and similar to that reported by Farias et al. (2003) in the analysis of 14 microsatellites of Arapaima in 15 individuals caught in Santarém City, Pará State, Brazil. This high genetic variability found in our analysis also corroborates the findings of Hrbek et al. (2005) for two mtDNA segments in several Arapaima populations in the Amazon Basin.

The multiplex panel of eight microsatellites developed in this study was shown to be capable of quantifying the genetic variability of the Arapaima population investigated. The results indicate that it can be used as a fast and inexpensive method with high discriminating power to evaluate the variability of Arapaima populations.

\section{ACKNOWLEDGMENTS}

Research supported by Conselho Nacional de Desenvolvimento Científico e Tecnológico (CNPq) and Financiadora de Estudos e Projetos (FINEP).

\section{REFERENCES}

Excoffier L, Laval G and Schneider S (2005). Arlequin 3.01: An integrated software package for population genetics data analysis. Evol. Bioinformatics Online 1: 47-50.

Farias IP, Hrbek T, Brinkmann H, Sampaio I, et al. (2003). Characterization and isolation of DNA microsatellite primers for Arapaima gigas, an economically important but severely over-exploited fish species of the Amazon basin. Mol. Ecol. Notes 3: 128-130.

Hrbek T, Farias IP, Crossa M, Sampaio I, et al. (2005). Population genetic structure of Arapaima gigas, world's biggest freshwater fish: implications for conservation. Anim. Conservation 8: 297-308.

Lüling KH (1964). Zur biologie und ökologie von Arapaima gigas (Pisces, Osteoglossidae). Z. Morph. Okol. Tiere 54: 436-530.

Neff BD, Fu P and Gross MR (2000). Microsatellite multiplexing in fish. Trans. Am. Fish. Soc.129: 584-593.

Perez-Enriquez R, Takagi M and Taniguchi N (1999). Genetic variability and pedigree tracing of a hatchery-reared stock of red sea bream (Pagrus major) used for stock enhancement, based on microsatellite DNA markers. Aquaculture 173: 413-423.

Rozen S and Skaletsky HJ (2000). Primer3: Bioinformatics Methods and Protocols. In: Methods in Molecular Biology (Krawetz S and Misener S, eds.). Humana Press, New Jersey, 365-386. http://frodo.wi.mit.edu/cgi-bin/primer3/ primer3_www.cgi.

Saint-Paul U (1986). Potential for aquaculture of South American freshwater fishes: a review. Aquaculture 54: 205-240.

Sambrook J, Fritsch EF and Maniatis T (2001). Molecular cloning: A Laboratory Manual. 3rd edn. Cold Spring Harbor Laboratory Press, New York. 